\title{
A COMPARATIVE STUDY OF INSTEP GRAFT WITH FULL THICKNESS GRAFT IN DIGITAL VOLAR CONTRACTURES
}

\author{
M. Mithran'1, Sheetal Sasidharan², Ravi Raman ${ }^{3}$
}

${ }_{1}^{1}$ Assistant Professor, Department of Orthopaedics, Velammal Medical College, Madurai, Tamilnadu, India.

${ }^{2}$ Assistant Professor, Department of Orthopaedics, Velammal Medical College, Madurai, Tamilnadu, India.

${ }_{3}^{3} \mathrm{HOD}$, Department of Orthopaedics, Velammal Medical College, Madurai, Tamilnadu, India.

\section{BACKGROUND}

ABSTRACT

Burns injury results in flexion contracture of fingers. Release of hand contractures leads to deficiency of skin that necessitates skin grafting1. The grafted skin should have a good colour match, durability with minimal donor site morbidity2. This study compares the use of plantar instep graft with full thickness graft in reconstruction of volar skin defects in flexion contractures of digits.

\section{METHODS}

A total of 6 patients- 5 paediatric, 1 adult patient were included in the study. Aetiology being 5 post burn contractures and 1 posttraumatic scar contracture limited distal to distal palmar crease. Contracture release was done for all patients, following which for 3 patients, raw area was covered with instep grafting and 3 patients had full thickness grafting of defect. Splinting of Instep grafts: 3 weeks +2 weeks and for full thickness grafts: 3 weeks; these patients were followed up for period of six months.

\section{RESULTS}

Both techniques had their own advantages and disadvantages. Ideal colour and texture match were good, with inconspicuous donor site, in instep graft. Instep graft replaced like tissue with like. While in full thickness graft, durability of the graft was good. It is good for paediatric cases as the graft stretches as patient grows. Donor site can be primarily closed.

\section{CONCLUSIONS}

Patient compliance, education and supervision is imperative for optimal long-term outcomes. Final outcomes are influenced greatly by hand therapy exercises and splinting.

HOW TO CITE THIS ARTICLE: Mithran M, Sasidharan S, Raman R. A comparative study of instep graft with full thickness graft in digital volar contractures. J. Evolution Med. Dent. Sci. 2019;8(25):2028-2030, DOI: 10.14260/jemds/2019/446

\section{BACKGROUND}

Burns injury results in flexion contracture of fingers. Release of hand contractures leads to deficiency of skin that necessitates skin grafting. The grafted skin should have a good colour match, durability with minimal donor site morbidity. This study compares the use of plantar instep graft with full thickness graft in reconstruction of volar skin defects in flexion contractures of digits.

\section{METHODS}

A total of 6 patients - 5 paediatric, 1 adult patients. Aetiology being 5 post burn contracture and 1 post-traumatic scar contracture limited distal to distal palmar crease. Contracture release was done for all patients, following which for 3 patients, raw area was covered with instep grafting and 3 patients had full thickness grafting of defect. Splinting of Instep grafts: 3 weeks +2 weeks and for full thickness grafts: 3 weeks.

'Financial or Other Competing Interest': None.

Submission 27-01-2018, Peer Review 04-03-2018,

Acceptance 10-03-2018, Published 24-06-2019

Corresponding Author:

M. Mithran

Muthu Hospital,

Krishna Rao Tank Street,

Madurai-625001,

Tamilnadu, India.

E-mail:drmithran@gmail.com

DOI: 10.14260/jemds/2019/446

\section{(c) $(\mathbf{F})$}
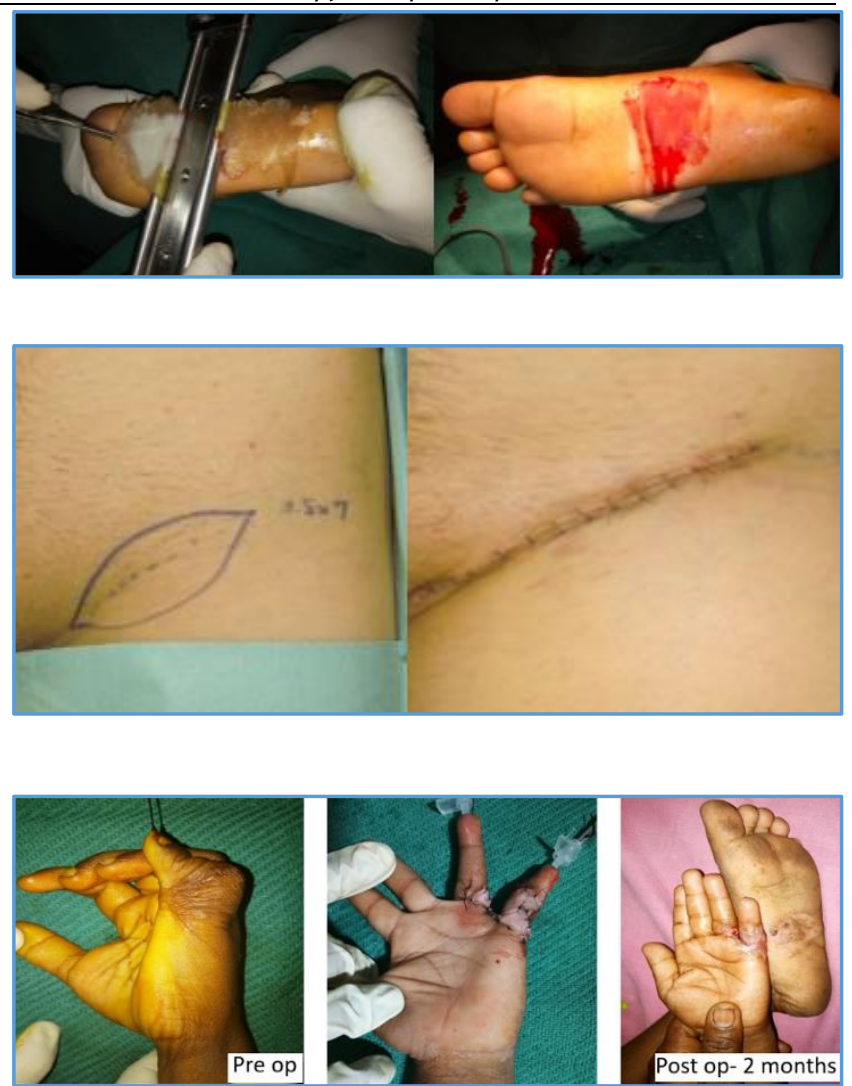

Case 1. 4 Yrs./M 


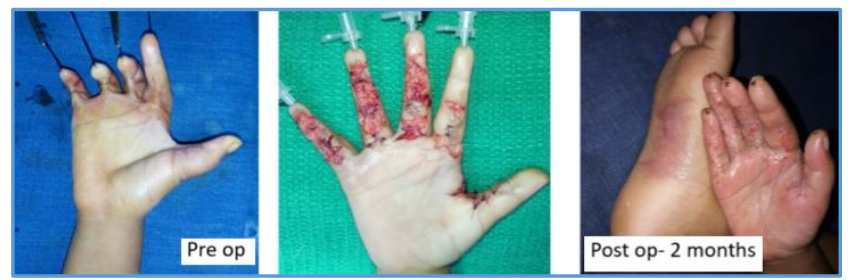

Case 2.8 Yrs./F

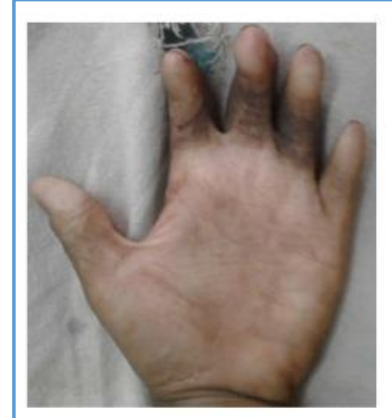

Pre op

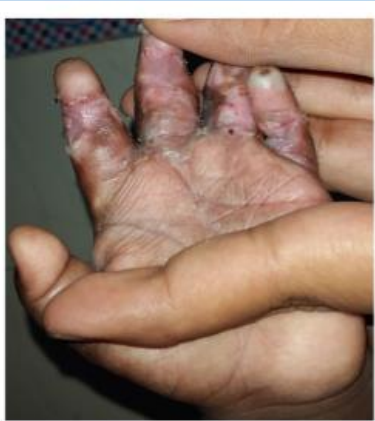

Post op- 1 and half month

\section{Case 3.5 Yrs./M}

\section{Instep Graft}

A partial thickness graft was harvested from the instep region of the sole of the foot.

\section{Full Thickness Graft}

- Groin donor site for the harvest.

- $\quad$ Size of the defect = dimension of graft.

- Cleared of any fat.

- Donor area closed primarily using Ethilon suture.

- Under anaesthesia.

- Under tourniquet control with pressure of $250 \mathrm{mmHg}$.

- Release of scar contracture was done primarily.

- Soft tissue splinting of digits done maintaining finger extension.

Based on the amount of skin deficiency produced after the contracture release, it was decided to provide-

- Instep graft.

- Full thickness graft.

- The grafts were given inset. Grafts were covered with tie-over dressings that remained in their place for 8-10 days.

- Volar blocking splint applied with fingers in complete extension.

- Hand elevation using a pillow cover.

- Donor dressing- in step region for 3 weeks.

- Splinting-

1. Instep grafts: 3 weeks +2 weeks.

2. Full thickness grafts: 3 weeks.

- Mobilisation- Started after 3 weeks.

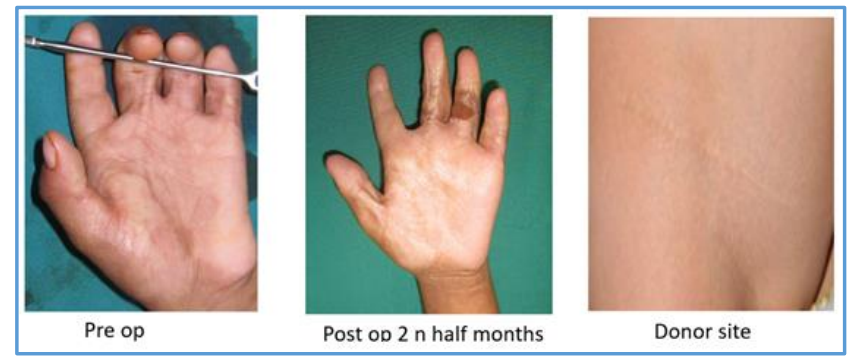

Case 4. 8 Yrs./F

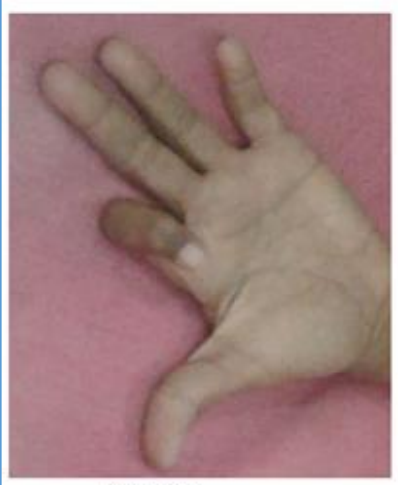

Pre op

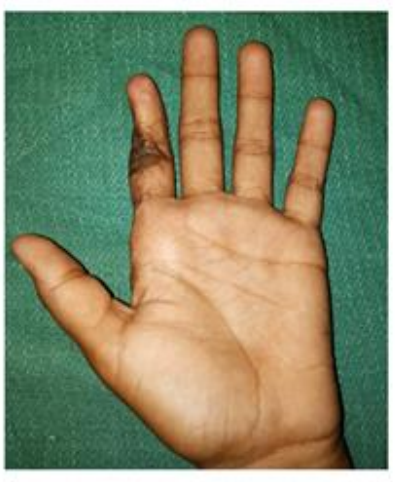

Post op- 2 and half months

Case 5.8 Yrs./M
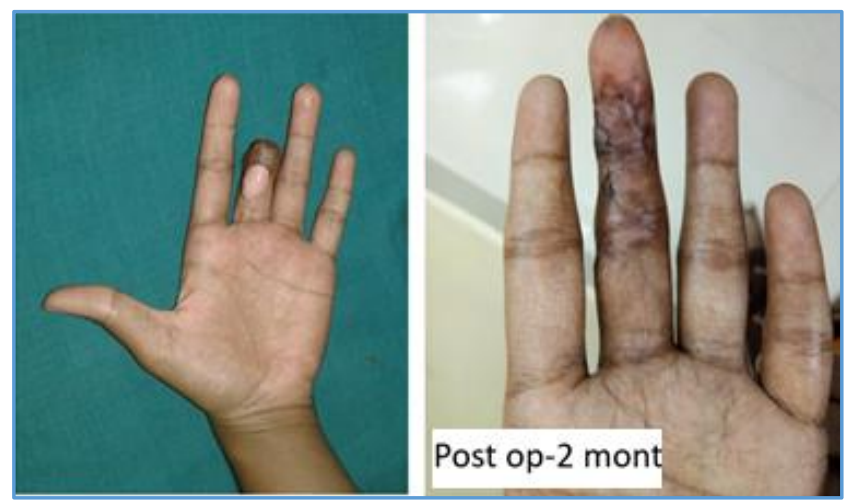

Case 6. 17 Yrs./F

\section{RESULTS}

- 6 patients- 5 paediatric, 1 adult.

- $\quad$ Studied for 6 months.

\begin{tabular}{|c|c|c|c|}
\hline & FACTORS & INSTEP GRAFT & FULL THICKNESS GRAFT \\
\hline 1 & $\begin{array}{l}\text { Colour match with surrounding } \\
\text { skin }\end{array}$ & Very good ++ & Hyperpigmented \\
\hline 2 & Epithelialisation & $\begin{array}{l}\text { Almost complete with } \\
\text { minimal patchy loss } \\
\text { healed by secondary } \\
\text { intention ++ }\end{array}$ & $\begin{array}{l}\text { Patchy loss healed by } \\
\text { secondary intention }\end{array}$ \\
\hline 4 & Durability & Good & Longer ++ \\
\hline 5 & Texture match & Good ++ & Good \\
\hline 6 & Donor site morbidity & Less & Absent, closed primarily \\
\hline
\end{tabular}

\section{Instep Graft}

- Ideal colour and texture match were good in instep graft.

- Inconspicuous donor site in instep graft.

- By replacing like tissue with like.

- Chance of re-contractures was higher in instep graft. 


\section{Full Thickness Graft}

- Durability of the graft was good.

- Good for paediatric cases - the graft stretches as patient grows.

- Advantage of donor site primary closure.

- Chances of hyperpigmentation is higher.

- Re-contractureless.

\section{DISCUSSION}

The basic differences between the palmar and dorsal surfaces of the hand reflect their different functions ${ }^{1}$. The dorsal skin is hair bearing, pigmented, soft and pliable. Surgeons have produced excellent aesthetic re- constructions of the dorsum of the hand by use of thin skin flaps, particularly the groin, lateral arm, posterior inter- osseous and radial forearm flaps $^{1}$. Conversely, the palmar skin is hairless, thicker, relatively non-elastic and characteristically light coloured in all races. The histology of the palmar surface reveals a welldefined stratum lucidum and thick stratum corneum and stratum spinosum. These features offer a serious challenge to any reconstructive surgeon involved in palmar resurfacing.

Flap cover is indicated when the underlying flexor tendons or skeleton are exposed or any of the soft tissues have required suture ${ }^{2}$. Local homodigital flaps fulfil the ideal of replacing 'like with like' and restrict the morbidity to the same finger or the palm. They are the preferred choice for reconstruction, but are limited by availability and size. Homodigital flaps are also unsuitable for circumferential defects $^{2}$. In clinical practice, homodigital flaps are mostly used to reconstruct defects limited to one of the three segments of the digit on either the palmar or dorsal side. These flaps are based on the principle of borrowing tissue from proximal and middle phalanx levels to reconstruct the distal phalanx but not vice versa. Other local flap techniques to reconstruct the palmar surfaces usually require skin grafting of the donor site ${ }^{3}$.

Cross finger flaps may be used to resurface defects on any number of segments of either the palmar or dorsal surfaces of a digit but may inflict significant morbidity of the donor site, require two procedures and delay rehabilitation 4 .

Axial pattern pedicled flaps (Radial forearm, reversed ulnar artery and posterior interosseous flaps) are used to cover defects of the palmar and dorsal surface of the hand. The medial and lateral arm flaps have been used successfully for hand resurfacing 4 . The donor sites can be closed directly up to a flap width of $5 \mathrm{~cm}$ to $8 \mathrm{~cm}$. These flaps can be raised as innervated flaps by including the antebrachial cutaneous nerves of the arm. However, the skin over the arm is nonglabrous, often hairy particularly on the lateral side and the donor site scar is visible and notorious for stretching over time. Recent experience in our unit has led to the frequent use of free 'mini' groin flap for digital resurfacing.

This flap provides soft, supple, non-hair bearing tissue with minimal donor site morbidity and a well-hidden scar4. The free anterolateral thigh flap is also used regularly for skin resurfacing. Although the donor site morbidity; in both flaps, is minimal, the flaps are insensate and provide non-glabrous skin which often requires multiple debulking procedures. The colour and texture match is in all the above skin flaps inferior to that found with the homodigital flaps and free instep flap. These flaps can match the colour and texture well on the dorsum of the hand and digits. However, the match is inferior to the instep flap when used for palmar resurfacing?

A free flap based on the superficial palmar branch of the radial artery (SUBRA Flap) has been used for digital reconstruction but is limited by size and useful in single digit defect. ${ }^{1}$

All these pigmented skin flaps, however thin and pliable when transferred on the light coloured, glabrous and nonhairy palmar skin, create a gross mismatch in colour and texture ${ }^{2}$. The aesthetic result is potentially inferior in ethnic groups with darker pigmented skin. Therefore, others have looked towards using glabrous skin options. The reverse thenar perforator flap has been used successfully for palmar resurfacing in Dupuytren's disease, trauma and burns. The glabrous palmar flaps, described recently as either a free or reversed pedicled palmar fasciocutaneous flap are ideal for replacing the 'like with like'1. However, if the flap width exceeds $2.5 \mathrm{~cm} 3 \mathrm{~cm}$, then primary closure of the donor site cannot be achieved without compromising the hand function. A free flap that fulfils the essential criteria for palmar/ volar resurfacing of digits is the free medial plantar artery (Instep) flap. It provides stable, pliable, durable, innervated, glabrous and non-hairy skin. It was first described by Shanahan as a flap to cover the defect on ipsilateral heel and as a free flap by Morrison for the same defect. It has been used to resurface whole palm defects and thumb contractures but its utility for digital resurfacing has yet to be fully exploited 4 .

\section{CONCLUSIONS}

Patient compliance, education and supervision is imperative for optimal long-term outcomes. Final outcomes are influenced greatly by hand therapy exercises and splinting.

\section{REFERENCES}

[1] Grossova R, Zajicek R, Kubok R, et al. The treatment of palmar contact burns in children: a five-year review. Annals Burns Fire Disasters 2017;30(1):5-8.

[2] Prasetyono TO, Sadikin PM, Saputra DK. The use of splitthickness versus full-thickness skin graft to resurface volar aspect of pediatric burned hands: a systematic review. Burns 2015;41(5):890-906.

[3] Chan QE, Barzi F, Harvey JG, et al. Functional and cosmetic outcome of full - versus split-thickness skin grafts in pediatric palmar surface burns: a prospective, independent evaluation. J Burn Care Res 2013;34(2):232-6.

[4] Jakubietz RG, Jakubietz MG, Kloss D, et al. Defining the basic aesthetics of the hand. Aesthetic Plast Surg 2005;29(6):546-51. 